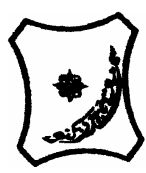

Bayero Journal of Pure and Applied Sciences, 9(2): 125 - 131

Received: August, 2016

Accepted: November, 2016

ISSN $2006-6996$

\title{
EFFECTS OF DIFFERENTLY PROCESSED SOYBEAN SUBSTITUTED DIETS ON NUTRIENT UTILIZATION AND THE GROWTH PERORMANCE OF Clarias gariepinus JUVENILES
}

\author{
Musa, M.I., Ndams, S. S., Musa, A. and Idujagi, S. \\ College of Agriculture and Animal Science, Ahmadu Bello University, Mando Road Kaduna \\ Correspondence author:musajordan@yahoo.com
}

\section{ABSTRACT}

Growth and nutrient studies was carried out on Clarias gariepinus Juveniles of mean weight 7.00-8.00g stocked into rectangular plastic aquarium tanks $30 \mathrm{~cm} \times 15 \mathrm{~cm}$ for 120 days fed with differently processed soya bean meal. There were eight treatments labeled as diet $T_{1}-T_{8}$, diet $T_{1}$ (control diet; contains no soybean meal but has fishmeal as the protein source); diet $T_{2}$ (Conventional diet; purchased commercially); diet $T_{3}$ (contains a partial replacement of fishmeal with raw soybean meal at 66.7 replacement) diet $T_{4}$ (has $100 \%$ of raw soybean meal inclusion), diet $T_{5}(66.7 \%$ toasted soybean inclusion); diet $T_{6}\left(100 \%\right.$ toasted soybean inclusion); diet $T_{7}(100 \%$ raw soybean with methionine and lysine); diet $T_{s}(100 \%$ toasted soybean with methionine and lysine). The diets were formulated at 40\% crude protein containing soya bean meal at different inclusion rates; the toasted soya bean was toasted at $100^{\circ} \mathrm{C}$ for 10 minutes using an oven and then milled into a fine powder before being mixed with other ingredients. Results showed that the highest average weight gain of $432.55 \mathrm{~g}$, specific growth rate (SGR) of $3.38 \%$ and food conversion ratio (FCR) of 5.78 of the formulated diets respectively were recorded in fish fed with diet $T_{5}$ (toasted soyabean meal) $P<0.05$. The Juveniles fed raw soybean gave the least growth performance (Diet $T_{3}$ ) and (Diet $T_{4}$ ) $P>0.05$. this relative lower growth performance of the fish might be attributed to the presence of higher levels of anti-nutritional factors present in soybeans for example trypsin inhibitors and phytic acid which may interfere with the availability of nutrients to the fish; from the result It could be concluded in practice that toasted soybean based diet is optimal for growth of Clarias gariepinus Juvenile. Mortality rates recorded during the dietary trial ranged between $30 \%$ in fish fed diet $T_{s}$ to $100 \%$ in the remaining diets. The results were discussed in relation to fish feed production and its implication for fish culture intensification in Nigeria and it is recommended that toasted soya bean should be embraced as the most preferred treatment for the soyabean used in fish feed Keywords: Processed soya bean, fishmeal, growth Juveniles, Clarias gariepinus.

\section{INTRODUCTION}

Several source of plant proteins (Legume seeds) have been evaluated as partial or complete replacements for fish meal in fish diets. Soybean meal is a major alternative protein source in fish diets (Lovell, 1988), it appears to be the most promising candidate for replacing part or all of fishmeal protein in fish diets Murai et al., (1986), Dabrowsky et al., 1989; Mohsen and Lovell, 1990). However, the growth rates tend to be low in fish fed with soybean meal replacing the entire fish meal sources (Jackson et al., 1982). This poor growth is attributed to the high activity of protease inhibitors in raw and in-adequately processed soybean meals (Viola, et al., 1982) Soybean is regarded as one of the best protein sources for having a balanced amino acid profile, it can be used as a replacement to a considerable amount of fishmeal diet in omnivorous freshwater fish such as carp, Tilapia and Catfish. According to Osuigwe (1995), no single processing method employed for the processing of soybean is complete without having the need for supplementing some essential amino acids. Soybean protein products can be good substitutes for animal products because, unlike some other beans, soybean offers a complete protein profile that is essentially identical to the protein of other legume seeds and pulses. Anti nutrients have been defined as a substance which by themselves or through their metabolic products arising in living systems, interfere with food utilization and affect the health and production of animals. (Makkar, 1993). The study is meant to access the suitability of replacing fish meal with soybean meal in the diet of Clarias gariepinus.

\section{MATERIALS AND METHODS}

Procurement of Experimental Catfish

Two hundred Clarias gariepinus Juveniles were purchased from the Bagauda fish farm located $60 \mathrm{~km}$ Southeast of Kano metropolis; they were transported in a 100 litre water filled plastic can (cut at the top to provide aeration) which were later placed into two plastic tanks for 48 hours before stocking into experimental tanks. 
The Juveniles were acclimatized for 48 hours before the feeding trial commenced, they were stocked in a rectangular plastic aquarium tanks $(30 \mathrm{~cm} \times 15 \mathrm{~cm} \times$ $15 \mathrm{~cm}$ ) at a stocking rate of 10 Juveniles per tank in duplicate. They were fed twice daily at $5 \%$ of their body weight (Alatise, 2004).

\section{Processing and Preservation of Dietary Ingredients}

Ingredients used for the diet formulations are soybean, yellow maize, groundnut cakes, fish meal, palm oil, vitamin premix. The Raw soybean was toasted at 100 oc for 10minutes (Eyo, 1991) in an electric oven then milled using a small grinder and stored in a freezer until required.

Groundnut cake was purchased from the local oil milling industry, while, maize was prepared by simply grinding the maize into fine powder (Sado, 1988) with hammer mill and the vitamin/mineral premix was purchased commercially from the phed Agrovet shop along Sani Abacha Road, within Kano metropolis. Proximate analysis was carried out on the feeds in the laboratory to determine moisture content estimation, ash content estimation, crude fibre estimation (C.F.E) Lipid content analysis, crude protein estimation and NFE as described by AOAC (1975).

\section{Feed Formulation}

The pearsons distribution square method of balancing protein was used as described by Sado, 1988, which involves the use of crude protein and energy values, the weighted ingredients were mixed in a plastic bowl, starch of cassava origin and water were added to make a dough which was pelleted using a screw type pelletizer to $2 \mathrm{~mm}$ diameter sizes, the pelleted feeds were collected and air dried for 2 days and stored in plastic containers before taken for analysis. The formulated diets were compounded to have $40 \%$ crude protein.

\section{Experimental Design}

Two hundred mixed Juveniles (7-8gm mean weight) were randomly distributed into rectangular plastic aquarium tanks $(30 \mathrm{~cm} \times 15 \mathrm{~cm} \times 15 \mathrm{~cm}$ at a stocking rate of 10 Juveniles per tank in duplicate; each dietary treatment was replicated and individually fish were weight at the start of the experiment; each experiment was conducted for 16 weeks. Water change was affected everyday to avoid accumulation of waste products and the plastic aquaria were covered with a soft metal nettling to prevent fish from jumping out.

\section{Experimental Site}

The experiment was conducted at the department of biological Science, Bayero University Kano, at the laboratory (aquarium); Located at Latitude $11^{\circ} 58^{\prime} 57$. $3^{\prime} \mathrm{N}$ and Longitude $8^{\circ} 31^{\prime} 31.1^{\prime} \mathrm{E}$ (Indabawa I., 2009).

\section{Statistical Analysis}

The Biological data arising from the treatment were subjected to descriptive analysis and differences in means were determined using the least significance difference (LSD) test and the significance was defined as $P<0.05$. All statistical analysis, the sum, the mean, standard deviation and the range (minimum-maximum) were done using the soft ware SP SS version 15.1.

\section{Analysis of Data}

Growth responses and nutrient utilization parameters were calculated as follows:

a. Average daily growth rate (DGR)

DGR $=\left(\frac{w f-w_{1}}{t}\right)$

Where: $\mathrm{wf}=$ final average weight at the end of the experiment

$\mathrm{W}_{1}=$ Initial average weight at the beginning of the experiment

$t=$ culture period in days

b. Specific Growth rate (SGR) \% per day

$\mathrm{SGR}=100 \times\left(\right.$ in wf in $\left.\mathrm{W}_{1}\right)$

$\mathrm{t}$

Where: $w f=$ final average weight at the end of the experiment

W1 $=$ Initial average weight at the beginning of the experiment

$\mathrm{t}=$ Culture period in days

c. Protein efficiency Ratio (PER)

PER $=\underline{\text { Weight gain of fish }}$

Protein intake of fish

d. $\quad$ Feed conversion Ratio (FCR)

$\mathrm{FCR}=\underline{\text { Dry weight of diet }(\mathrm{g})}$

Weight gain by fish $(\mathrm{g})$

e. $\quad$ Survival rate (SR) \%

$$
\text { SR \& }=\underline{N}_{1} \times \frac{\mathrm{X} 100}{\mathrm{~N}_{\mathrm{o}}}
$$

Where: $N_{1}=$ Total number of fish at the end of the experiment

No $=$ Total number of fish stocked at the beginning of the experiment.

As described by Adiaha (2007)

\section{Feeding Regime}

The experimental diets were offered to the fish in the experimental tanks twice daily at $8 . a m$ and $5 \mathrm{pm}$ feeding rate adopted was $5 \%$ bodyweight per day, the feed was divided into two equal portions, the fish ate almost all the feed offered to them, the left over feed was removed the next day, before another feed was given. The feeding trial lasted for 120 days and the diets were compounded to contain $40 \%$ crude protein with vary levels of processed soybeans, the diet with zero level soybean inclusions served as the control, the diets were compounded as follows.
Diet $\mathrm{T}_{1}$
- $\quad(0 \%$ inclusion of Soybean)
Diet $\mathrm{T}_{2}$
- (Coppens; Industrial fish feed)
Diet $\mathrm{T}_{4}$ 
Diet $\mathrm{T}_{5} \quad-\quad(66.7 \%$ Inclusion of Toasted soybean $)$

Diet $\mathrm{T}_{6} \quad-\quad(100 \%$ Inclusion of Toasted soybean $)$

Diet $\mathrm{T}_{7} \quad-\quad 100 \%$ Inclusion of raw soybean with $0.4 \mathrm{~g}$ methionine and $0.2 \mathrm{~g}$ lysine)

Diet $\mathrm{T}_{8} \quad-\quad$ (100\% Inclusion of toasted soybean with $0.4 \mathrm{~g}$ methionine and $0.2 \mathrm{~g}$ lysine)

The water quality parameters like dissolved oxygen, temperature $\mathrm{pH}$ were monitored using the standard method of examination as explained by Adigun, (2005) water temperature was measured using thermometer, while dissolved oxygen was measured using an oxygen meter, the $\mathrm{pH}$ of the water was measured using scan tester. Mortality was monitored daily and recorded accordingly.

\section{RESULTS AND DISCUSSION}

Proximate Composition of Experimental Diets

The physico-chemical parameter is presented in Table 1 and it was conducive for fish culture during the experiment.

Table 1: Means of Some Physico-Chemical Parameters of Water in the Plastic Aquaria Tanks in which Clarias gariepinus were Kept During the Period of Experiment.

\begin{tabular}{lcccccccc}
\hline & \multicolumn{10}{c}{ TREATMENT } \\
\hline Parameters & $\mathrm{T}_{1}$ & $\mathrm{~T}_{2}$ & $\mathrm{~T}_{3}$ & $\mathrm{~T}_{4}$ & $\mathrm{~T}_{5}$ & $\mathrm{~T}_{6}$ & $\mathrm{~T}_{7}$ & $\mathrm{~T}_{8}$ \\
Temperature & 25.5 & 25.0 & 25.0 & 25.0 & 25.0 & 25.0 & 25.5 & 25.0 \\
pH & 7.8 & 7.8 & 7.8 & 7.8 & 7.8 & 7.5 & 7.8 & 7.8 \\
Dissolve 02(mg/ht) & 5.50 & 5.60 & 5.50 & 5.50 & 5.55 & 5.50 & 5.55 & 5.50 \\
Conductivity & 2.30 & 2.30 & 2.30 & 2.30 & 2.30 & 2.30 & 2.30 & 2.30 \\
\hline
\end{tabular}

All fish fed actively appeared healthy, diet $T_{1}$ and diet $T_{2}$ (control diet and industrial diet coppens) have the highest crude proteins followed by $T_{5}\left(66.7 \%\right.$ inclusion of toasted soybean) while, diet $T_{4}$ has the least crude protein, a diet containing ( $100 \%$ inclusion of raw soybean). Table 3.

Table 2: Gross Composition of Experimental diets

\section{Grammes (g)}

Ingredients

a. Fish meal

b. Raw soybean meal

c. Row soybean meal with methionine lysine

d. Toasted soybean Meal

e. Toasted soybean meal with methionine lysine

f. Yellow maize

g. Groundnut cake

h. Vitamin Premix

i. Starch

j. Salt

k. Vegetable oil

I. Bone meal

\section{Treatments}

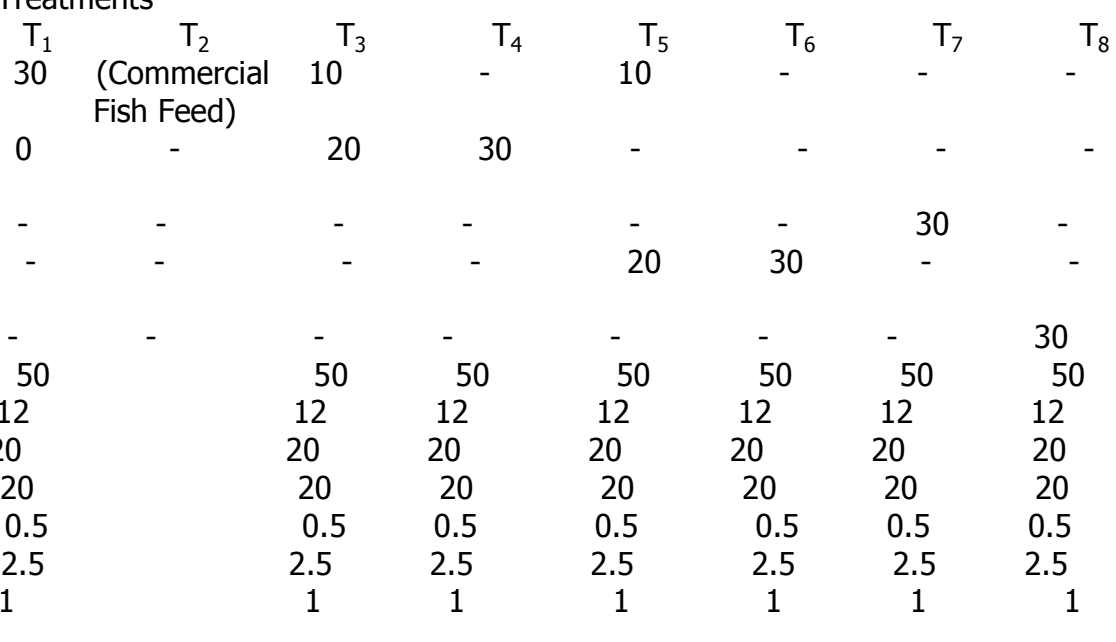

Table 3: Mean Values Composition of the formulated diets used in the experiments:

\begin{tabular}{|c|c|c|c|c|c|c|c|c|}
\hline Nutrient Contents \% & $\mathrm{T}_{1}$ & $\mathrm{~T}_{2}$ & $\mathrm{~T}_{3}$ & $\mathrm{~T}_{4}$ & $\mathrm{~T}_{5}$ & $\mathrm{~T}_{6}$ & $\mathrm{~T}_{7}$ & $\mathrm{~T}_{8}$ \\
\hline Crude protein & 45.40 & 44.97 & 39.24 & 39.20 & 42.00 & 40.10 & 42.10 & 41.20 \\
\hline Crude fat & 2.50 & 2.65 & 2.30 & 2.25 & 2.50 & 2.45 & 2.40 & 2.40 \\
\hline Crude Ash & 21.59 & 20.81 & 19.00 & 19.50 & 21.59 & 20.49 & 23.80 & 24.78 \\
\hline Crude fibre & 8.00 & 8.97 & 9.00 & 7.00 & 8.00 & 9.00 & 7.00 & 8.00 \\
\hline Moisture & 9.81 & 9.99 & 8.90 & 8.80 & 9.40 & 9.63 & 9.13 & 8.40 \\
\hline Nitrogen free Extract & 15.53 & 19.34 & 21.60 & 21.63 & 15.20 & 15.28 & 20.64 & 20.50 \\
\hline
\end{tabular}




\section{Growth Performance of Experimental Fish}

The result showed that diet $T_{2}$ (Industrial feed) had the highest weight gain of $470.2 \mathrm{~g}$ (Table 4) This was followed closely by diet $T_{5}$ with weight gain of $432.55 \mathrm{~g}$ (66.7\%) inclusion of toasted soya bean) also diet $T_{6}$ with weight gain of $304.7 \mathrm{~g}$ and $\mathrm{T}_{7}$ with $322.5 \mathrm{~g}$ (which are diets containing $100 \%$ inclusion of toasted soybean and $100 \%$ inclusion of raw soybean with methionine and lysine) followed closely. There was no significant different $(P>0.05)$ between diets $T_{2}$ and diet $T_{5}$ in weight gain, while diet $T_{6}$ and $T_{7}$ are significantly different $(P<0.05)$ from diets $T_{2}$ and $T_{5}$.

Based on the average weight gain, diet $T_{5}$ with $66.7 \%$ inclusion of toasted soyabean performed better and diets $T_{6}$ and $T_{7}$ followed closely. These result shows that use of soybean in fish feed (partial inclusion or fully substituted) in feed for Clarias gariepinus gave good growth rate, good food conversion ration and good protein utilization compared to the control diet (Table 5); Viola (1982) reported that partial replacement ( $40 \%$ of fishmeal) by soybean meal in pond trials of carp required only supplements of methionine at $50 \%$ level in order to attain the same growth, protein and energy utilization as that with the control ratio that had fish meal as the main protein supplement. In this study, total replacement of fish meal with soybean did not appear to significantly affect feed conversion ratio (FCR) and protein efficiency ratio (PER); Lovell, (1997) stressed that soybean protein has one of the best amino acid profile of all legumes and it is sufficient in meeting the amino acid requirement of fish the finding of this study agrees with the work of smith (2000) who claimed success of feeding rain-bow trout a diet based almost entirely on raw materials of vegetable origin containing $80 \%$ roasted soybean. Pantha, (2007) observed no significant different in growth performance and diet utilization in Oreochromis niloticus fed a diet where all the protein was supplied by herring meal and $75 \%$ of herring meal was replaced by full fat soybean cake supplemented by methionine. Jackson et al., (1992) also found no significant different in growth performance and diet utilization in Tilapia, Sarotherodon mossambicus fed a diet where $25 \%$ of a control diet was replaced by soybean meal. Feed ingredient of plant origin have shown to contain various anti-nutritional factor for instance, soybean contains haemoglutinin (Jackson 1992)) groundnut has aflatoxin (Rayfeltwell and sydfox, 1998) wheat offal has high fibre and low amino acid content (Gohl, 2005). However, some of these defects in these plants products can be ameliorated by heat and chemical treatment.

\section{Nutrient Utilization of Clarias gariepinus} Fingerlings Feed on Different Soybean Diets.

The nutrient utilization data is presented in table 5 ; the protein efficiency ratio (PER) was highest in fish fed with diet $T_{2}$ (industrial feeds) with a value of $11.80 \mathrm{~g}$ followed closely with diet $T_{5}(66.7 \%$ inclusion of toasted soybean mean) with a value of 10.81 , there is no significant different in diet $T_{2}$ and diet $T_{5}$; diet $T_{7}(100 \%$ inclusion of raw soybean meal with $0.4 \%$ methionine and $0.2 \%$ lysine) has a PER of 7.86 which was followed by diet $\mathrm{T}_{6}(100 \%$ inclusion of toasted soybean) with a value of 7.62. This shows that diet $T_{6}$ and $T_{7}$ are significantly different $(P<0.05)$ to diet $T_{2}$ and $T_{5}$. 
BAJOPAS Volume 9 Number 2 December, 2016

Table 4: Mean Values of Growth Performance of Clarias gariepinus Juveniles Fed on the Different Diets:

\begin{tabular}{|c|c|c|c|c|c|c|c|c|}
\hline Growth Parameters & $T_{1}$ & $T_{2}$ & $T_{3}$ & $T_{4}$ & $T_{5}$ & $T_{6}$ & $T_{7}$ & $T_{8}$ \\
\hline Average initial wt (g) & 7.0 & 7.3 & 7.7 & 7.3 & 7.7 & 7.8 & 8.0 & 7.8 \\
\hline Average final Wt $(\mathrm{g})$ & 295.0 & 477.5 & 245.25 & 262.5 & 440.25 & 312.5 & 322.5 & 290.40 \\
\hline Average Wt gain (g) & 288.0 & 470.2 & 224.55 & 255.2 & 432.55 & 304.7 & 314.5 & 282.2 \\
\hline Average daily Wt gain (g) & 0.024 & 0.039 & 0.019 & 0.021 & 0.036 & 0.025 & 0.026 & 0.024 \\
\hline Average \% Wt & 14.14 & 64.11 & 29.16 & 34.95 & 56.17 & 39.06 & 39.31 & 36.17 \\
\hline Average specific growth rate & 3.12 & 3.48 & 2.88 & 2.98 & 3.38 & 3.08 & 3.08 & 3.02 \\
\hline Percentage survival & 100 & 95 & 100 & 100 & 100 & 100 & 75 & 30 \\
\hline $\begin{array}{l}\text { Initial body length } \\
(\mathrm{cm}) \text { Average }\end{array}$ & 6.77 & 5.70 & 6.79 & 6.50 & 6.72 & 6.70 & 6.72 & 6.79 \\
\hline Final Body length (cm) & 20.50 & 28.70 & 21.70 & 22.75 & 27.80 & 26.80 & 16.80 & 17.40 \\
\hline Average Length Gain (cm) & 18.73 & 22.00 & 14.91 & 16.25 & 21.08 & 20.10 & 9.78 & 10.61 \\
\hline Survival Rate |(\%) & $100 \%$ & $100 \%$ & $100 \%$ & $100 \%$ & $100 \%$ & $100 \%$ & $100 \%$ & $30 \%$ \\
\hline
\end{tabular}

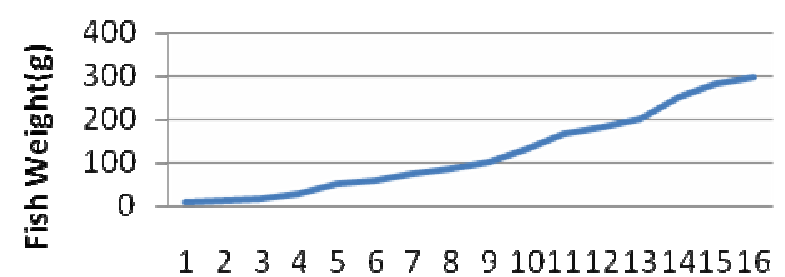

WEEK

Figure 1: Mean weight of fish fed with control meal $\left(T_{1}\right)$

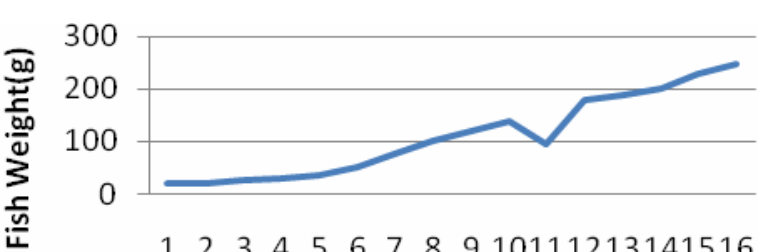

WEEK

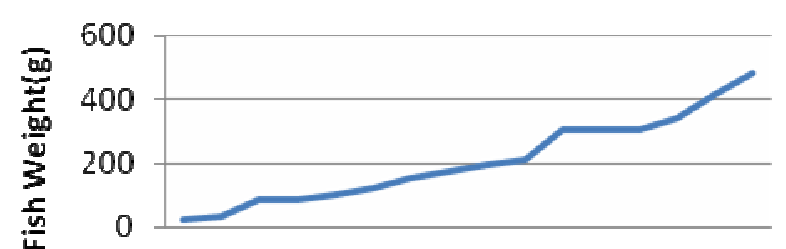

$123 \quad 4 \quad 5 \quad 6 \quad 7 \quad 8 \quad 910111213141516$

WEEK

Figure 2: Mean weight of fish fed with conventional feed $\left(T_{2}\right)$

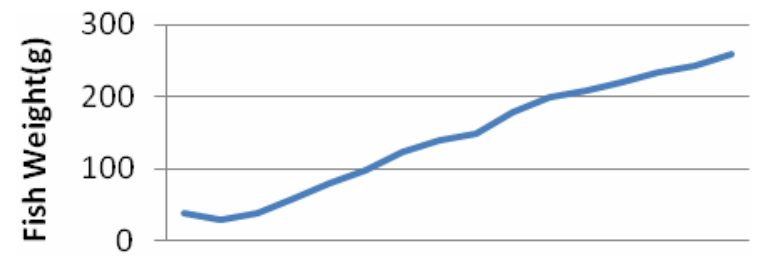

123456678910111213141516

WEEK

Figure 3: Mean weight of fish fed with $50 \%$ raw soybean meal $\left(T_{3}\right)$ Figure 4: Mean weight of fish fed with $100 \%$ raw soybean meal $\left(T_{4}\right)$ 

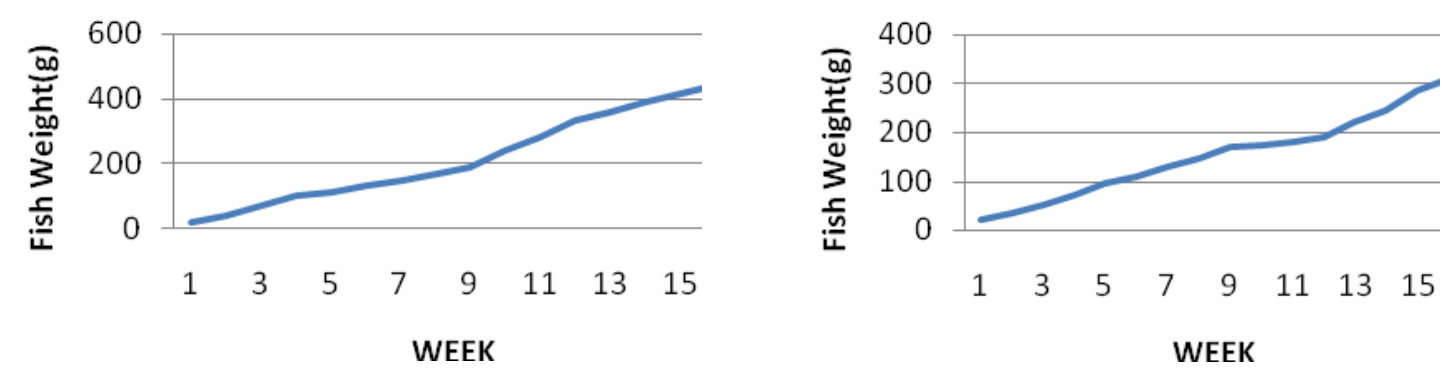

Figure 5: Mean weight of fish fed with 50\% toasted soybean meal $\left(T_{5}\right)$ Figure 6: Mean weight of fish fed with $100 \%$ toasted soybean meal $\left(T_{5}\right)$

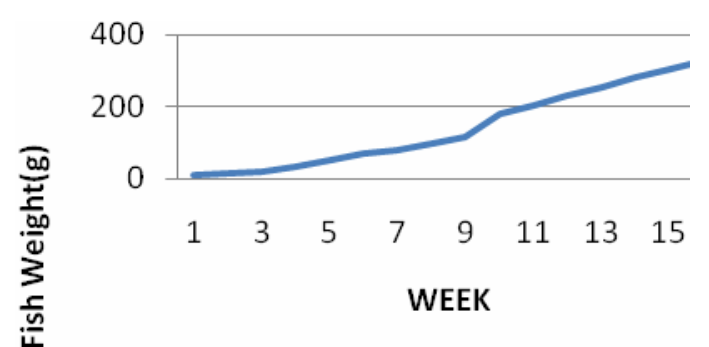

Figure 7: Mean weight of fish fed with $100 \%$ raw soybean meal plus methionine and lysine $\left(\mathrm{T}_{7}\right)$

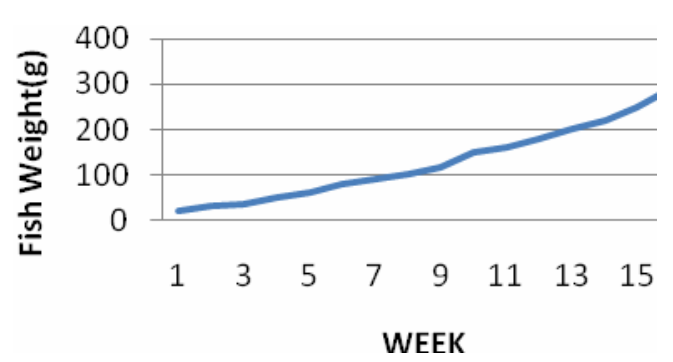

Figure 8: Mean weight of fish fed with $100 \%$ toasted soybean meal plus methionine and lysine $\left(T_{8}\right)$

Table 5: Nutrient Utilization of Clarias gariepinus Juveniles Fed on the Different Diets

\begin{tabular}{lcccccccc} 
Growth Parameters & \multicolumn{1}{c}{$\mathrm{T}_{1}$} & $\mathrm{~T}_{2}$ & $\mathrm{~T}_{3}$ & $\mathrm{~T}_{4}$ & $\mathrm{~T}_{5}$ & $\mathrm{~T}_{6}$ & $\mathrm{~T}_{7}$ & $\mathrm{~T}_{8}$ \\
\hline $\begin{array}{l}\text { Average Daily Weight } \\
\text { gain (g) }\end{array}$ & 0.024 & 0.039 & 0.019 & 0.021 & 0.036 & 0.025 & 0.026 & 0.024 \\
$\begin{array}{l}\text { Average protein } \\
\text { Efficiency ratio (PER) (g) }\end{array}$ & 7.2 & 11.80 & 6.11 & 6.40 & 10.81 & 7.62 & 7.86 & 7.10 \\
$\begin{array}{l}\text { Average Feed } \\
\text { Conversion ratio (FCR) (g) }\end{array}$ & 8.68 & 5.23 & 10.22 & 9.80 & 5.78 & 8.20 & 7.95 & 8.86 \\
Net Nitrogen Retention & 57.42 & 56.14 & 64.75 & 63.48 & 56.24 & 61.37 & 58.93 & 58.44 \\
\hline
\end{tabular}

The lowest feed conversion ratio (FCR) value of 5.23 was seen in diet $T_{2}$ while the highest FCR was obtained $T_{8}$. While diet $T_{1}$ (control diet) is significantly different $(P<0.05)$ from diet $T_{2}$, and diet $T_{5}$. The protein efficiently ratio $(P E R)$, feed conversion ratio (FCR) followed the same pattern as that of weight gain values (Tables 4 and 5). 


\section{Graphic Representations}

The graphic impressions of the bi weekly weight gain for the 16weeks is presented from fig. 1-8; it could be seen that diet $T_{2}$ (industrial feed coppens) has a continuous growth pattern from $1^{\text {st }}$ to the $10^{\text {th }}$ week but growth rate accelerated rapidly from the tenth to the end of the experiment. While figure 3, shows that mean weight of fish fed with diet $\mathrm{T}_{3}(66.7 \%$ inclusion of raw soybean meal) had a fall in the growth rate at the $10^{\text {th }}$ week, fish I this group had the poorest percentage weight gain $(224.55 \mathrm{~g})$. These showed that there was no depression in weight gain in these experimental diets.

\section{Survival Rate}

The survival rate of the fish during the experiment ranged from $30 \%-100 \%$ (table 4). The highest survival rate of $100 \%$ was recorded in all the diets with the exception of diet $\mathrm{T}_{7}$ which recorded a $30 \%$ survival rate. The high rate of survival in the experiment could be attributed to acceptability of the diets and a high level of nutrient utility in the fish.

\section{REFERENCES}

Adiaha A. A. Ugwumba and O. A. Ugwumba, 2007 Food and Feeding Ecology of Fishes in Nigeria Pp 58-61. CRYSTAL PUBLISHERS, Ajah, Lagos.

Adigun, B. A. (2005): Water Quality Management in Aquaculture and Freshwater Zooplankton Production for Use in Fish Hatcheries. Innovative Ventures New-Bussa Niger State PP. 1-11.

Alatise P. S; Ogunbele O; Eyo A. A. and Oladunjoye L.F. (2004); Evaluation of Different Soybean Based Diets on Growth and Nutrient Utilization of Heterobranchus Longifilis in Aquaria Tanks. Journal of Fisheries Society of Nig. 2004 Edition Pp. 255262.

Dabrowsky K. and Kozak B. (1989). The Use of Fishmeal and Soybean as a Protein Source in the Diet of Grass Carp fry Aquaculture 18: 107-114.

Eyo A. A. (1991) -Chemical Composition and Nutrition Value of the Community Available Feed Stuffs Used in Fish Feed in Nigeria; NIFFR Annual Report PP. 99-133.

Gohl, B. (2005). Tropical Feeds. Food and Agricultural Organisation of the United Nations, Rome.

Indabawa, I. I. 2009 Defection of Variants of Some Microcystin Produced by Microcystis aeruginosa in some Burrow pits of Kano Nigeria. Bayero Journal of Pure and Applied Sciences, 2(1)PP189.

Jackson A. J. and Capper, B.S (1992). Investigation into the Requirements of the tilapia Sarotheroden mossambiscu for Dietary Methionine Lysine and Arginine in Semisynthetic diets Aquaculture 2 (289297).

Jackson A. J. and Capper, B.S and A. J. Matty (1982). Evaluation of Some Plant Protein in Complete Diets for Tilapia (Sarotheroden mossambicus) Aquaculture 27:97-109.

\section{CONCLUSION}

From the feeding trials of Clarias gariepinus fed with different soybean diet. Diet $T_{5}$ (with $66.7 \%$ inclusion of toasted soybean gave a very good performance in comparison to the control (diet $\mathrm{T}_{1}$ )

\section{Recommendations}

- Toasted soyabean should be embraced by fish farmers as the most preferred treatment for soybean used in fish feed.

- Animal protein should be substituted partially or fully with soybean provided the essential amino acid (methionine and lysine) are added to improve feed in order to maximize profit.

- The toasting of soyabean should be done in a sufficient way so as to reduce the effect of inhibitors and provide a flavor to the feed.

- That toasted soyabean can be recommended where fish meal is not available.

Lovell R. T. (1988): Use of Soybean Products in Diets for Aquaculture Species. Journal

of Agricultural Production 2: 27-52.

Lovell, T. (1997): Nutrition and Feeding of Fish Van Nostrand Reinhold, New York, 260pp.

Makkar HPS, (1993). Annual Production in Developing Countries. Anti- Nutritional Factors in Foods for Livestock (eds) Gill. M., Owen E, Pallot, G.E and Lawrence, T. L. J. Occasional Publication No. 16 British Society of Animal Production Pp. 69-85.

Moshen, A. A. and Lovell, T. T. (1990). Partial Substitution of Soybean Meal with Animal Protein Sources in Diets for Channel Catfish - Aquaculture 90, pp. 303-322.

Munrai T., Ogata H. Kosutarak P. and Arai S. (1986). Effects of Amino Acid Supplementation and Methanol Treatment on Utilization of Soya Bean Flour by Fingerling Carp. Aquaculture 56; PP 197206.

Osuigwe D. I. (1995); Effect of Processed Soyabean Substituted Diets on Growth of Juvenile 0. Niloticus; Journal of Agricultural Tech. Pp. 75-78.

Pantha, N. B. (2007) The use of Soya bean in practical feeds for Tilapia, Oreochromis niloticus, Msc Thesis, University f Sterling, Scotland, U.K.

Rayfeltwell, A.C and Sydfox, A. G (1998). Practical Poultry Feeding Macmillan Ltd. London pp.

Sado E. K. (1988) Fish Feed Formulation and Nutrition; Lecture Delivered at the Fish Farmers Workshop on Aquaculture Under the Auspices of DFFRI from $29^{\text {th }}$ Aug. $-6^{\text {th }}$ Oct, 1988. Research Aquaculturist, NFFRI, New Bussa.

Smith B. W. and Lovell, R.T (2000). Digestibility of Nutrients in Rainbow Trout Stainless Steel Travahs, Proc. Annual Conference.

Viola, S; Mokady, S; Rappaport V. and Arielli Y. (1982). Partial and Complete Replacement of Fish Meal by Soybean Meal in Feeds for Intensive Culture of Carp. Aquaculture 26; pp. 223-236. 